\title{
Seasonal Incidence of Major Insect Pests of Potato (Solanum tuberosum L.) and their Correlation with Abiotic Factors under Foothill Conditions of Nagaland
}

\author{
Imlilemla Amlari ${ }^{1}$, Pankaj Neog ${ }^{1}$ and Noyingthung Kikon ${ }^{2}$ \\ ${ }^{1}$ Department of Entomology, ${ }^{2}$ Department of Agronomy, School of Agricultural Sciences and \\ Rural Development, Nagaland University, Medziphema - 797106, Nagaland, India \\ *Corresponding author
}

Keywords

Seasonal incidence, potato, potato aphid, whitefly, leafhopper and mealybug

Article Info

Accepted: 15 June 2021 Available Online: 10 July 2021

\section{A B S T R A C T}

A field experiment was conducted at Experimental Farm, School of Agricultural Sciences and Rural Development, Nagaland University, Medziphema Campus during Rabi season of 2016-17 to study the effect of weather parameters on incidence of major insect pests infesting potato crop. Leafhopper appeared during $46^{\text {th }}$ SMW (Standard mean week), while first incidence of potato aphid, whitefly and mealybug was seen on $47^{\text {th }}$ SMW. The peak populations of potato aphid were observed in $4^{\text {th }}$ SMW with a mean population of 23.93 per three leaves. Whitefly (1.67 per three leaves), leafhopper (1.87 per three leaves) and mealybug (3.20 per three leaves) were observed in $1^{\text {st }}, 3^{\text {rd }}, 1^{\text {st }}$ SMW, respectively. Whitefly, leafhopper and mealybug demonstrated non-significant negative association with minimum temperature $(\mathrm{r}=-0.457,-0.467$ and -0.506 , respectively) but significant negative correlation $(\mathrm{r}=-0.744)$ in potato aphid. Negative significant correlation was recorded $(\mathrm{r}=-$ $0.658,-0.692,-0.862$ and -0.821 ) of maximum temperature with potato aphid, whitefly, leafhopper and mealybug, respectively. Minimum relative humidity was non-significant negatively correlated $(r=-0.398,-0.037,-0.018$ and -0.069$)$ with potato aphid, whitefly, leafhopper and mealybug, respectively. Potato aphid and mealybug infestation had negative non-significant correlation ( $\mathrm{r}=$ 0.345 and -0.024 , respectively) with maximum relative humidity, but nonsignificant positive correlation ( $\mathrm{r}=0.157$ and 0.105$)$ in leafhopper and whitefly, respectively. Rainfall showed positive non-significant correlation ( $\mathrm{r}=0.330$, 0.232 and 0.390) with whitefly, leafhopper and mealybug, respectively. Aphid population was non-significant negatively correlated $(r=-0.163)$ with rainfall. 


\section{Introduction}

Potato (Solanum tuberosum L.) popularly known as 'The king of vegetables' is the $4^{\text {th }}$ most important food crop in India after rice, wheat and maize. It is a highly nutritious food and contains $74.70 \%$ water, $22.60 \%$ carbohydrates (Starch and Sugar), 1.6\% proteins, $0.40 \%$ fibre, $0.10 \%$ fat, $0.60 \%$ minerals and $17 \%$ vitamin $\mathrm{C}$ per 100 gms. Being a short duration crop, it produces more quantity of dry matter, edible energy and edible protein in lesser duration of time than cereals like rice and wheat. Hence, potato may prove to be a useful crop to achieve the nutritional security of the nation. Worldwide 376.45 million tons of potatoes are produced every year from 19.12 million ha (Anonymous, 2015). In India the total production of potato is 45951 thousand tonnes over 2069 thousand ha (Anonymous, 2015). Potato is an important crop in the North Eastern Region of India and accounts for 10\% of the country's total potato area and $4 \%$ of the total production. In Nagaland potato is grown over a total area of 4.82 thousand hectares with a productivity of 65.10 thousand tonnes (Anonymous, 2015). Globally, potato production suffers due to plant damage by many pests at different stages of crop growth (Shakur et al., 2007; Basavaraju et al., 2009). Global losses up to 10-16 per cent have been estimated due to various insect pests and viruses in potato crop (Dhaliwal et al., 2010). Among the insect pests, aphid (Myzus persicae) being a worldwide pest with wide host range of a number of plant families (Blackman and Eastop, 2000; Brunissen et al., 2009) is an important pest in potato. It gained high importance by virtue of being a vector of viral diseases (Blackman and Eastop, 2000), including potato virus Y (PVY) and potato leaf roll virus (PLRV) that causes yield losses up to 13.9-20 per cent. Therefore, the present investigation was carried out to study the seasonal incidence of insect pests of potato and their natural enemies under foothill conditions of Nagaland so that proper management strategy can be formulated.

\section{Materials and Methods}

The investigation was carried out during rabi season of 2016-17 in the experimental farm of School of Agricultural Sciences and Rural Development, Nagaland University, Medziphema, Nagaland. The experiment was conducted in three ecological plots of size $4 \mathrm{x}$ $3 \mathrm{~m}^{2}$ maintaining a distance of $1 \mathrm{~m}$ from each other with the variety Kufri Jyoti, which was sown during the last week of October 2016 maintaining a spacing of $50 \mathrm{~cm} \times 25 \mathrm{~cm}$. All the recommended agronomic practices were followed. Incidence of major insect pests of potato was observed at weekly intervals throughout the cropping period from five randomly selected tagged plants per plot. The incidence of various insect pests was estimated by making count of the population of insect pests. Observation on aphid, whitefly and mealybug population was recorded by counting both the nymphs and the adults from 3 leaves i.e. top, middle and bottom per plant. Leafhopper population was taken by adopting the sweep method using a hand net. Three sweeps per plot was taken into account. Similarly the population of natural enemies $v i z$. , lady bird beetle and spider was observed and recorded by visual observation from five randomly selected tagged plants per plot. The data recorded was subjected to simple correlation studies to find out the effect of abiotic factors viz., temperature, relative humidity and rainfall on the incidence of major insect pests and their natural enemies.

\section{Results and Discussion}

The findings on incidence of major insect pests of potato and their natural enemies during rabi season of 2016-17 and correlation coefficient of insect pest and natural enemy 
population with weather parameters are discussed as follows.

\section{Seasonal incidence of insect pests}

\section{Potato aphid (Myzus persicae)}

Myzus persicae was first recorded during $47^{\text {th }}$ SMW on potato. The activity period of aphid was observed from $47^{\text {th }}$ to $7^{\text {th }}$ SMW $\left(20^{\text {th }}\right.$ November, 2016 to $12^{\text {th }}$ February, 2017). The highest population was observed in $4^{\text {th }}$ SMW with a mean number of 23.93 per leaf, while the lowest was recorded in $47^{\text {th }}$ SMW with a mean number of 1.45 aphids per leaf (Table 1). The present findings are more or less similar with those recorded by Konar and Singh (2009) who reported that in Kufri Jyoti, aphids was observed first by fourth week of December and attained the critical level during second to third week of January. Correlation coefficient of various weather parameters and $M$. persicae population were found nonsignificant. However the pest showed a significant negative correlation with minimum $(\mathrm{r}=-0.744)$ and maximum $(\mathrm{r}=-0.658)$ temperature (Table 2). The present findings are in agreement with the report of Ebwongu et al., (2001) who reported that, the correlation studies registered negative correlation of relative humidity with the aphid incidence.

\section{Whitefly (Bemisia tabaci)}

Bemisia tabaci was first observed on potato crop during $47^{\text {th }}$ SMW. The activity period of Bemisia tabaci was observed from $47^{\text {th }}$ to $7^{\text {th }}$ SMW (20 $0^{\text {th }}$ November, 2016 to $12^{\text {th }}$ February, 2017). Investigation on the incidence of Bemisia tabaci revealed that the highest incidence was recorded during $1^{\text {st }}$ SMW $\left(1^{\text {st }}\right.$ January, 2017) with a mean number of 1.67 per leaf, while the lowest was recorded on $47^{\text {th }}$ SMW $\left(20^{\text {th }}\right.$ November, 2016) with a mean number of 0.20 per leaf (Table 1). The present results are in accordance with Bhatnagar
(2007) who opined that, the incidence of whitefly population declined in the month of November. Correlation studies between whitefly population and abiotic factors were found non-significant, except maximum temperature $(\mathrm{r}=-0.692)$ which exhibited a significant positive correlation (Table 2).

The present investigation is also similar with Lanunochetla et al., (2012) who reported that the maximum temperature and relative humidity showed positive as well as negative non-significant correlation, whereas both minimum temperature and rainfall showed negative non-significant correlation with the whitefly population.

\section{Leafhopper (Amrasca biguttula biguttula)}

Amrasca biguttula biguttula was first observed during $46^{\text {th }}$ SMW on potato. The activity period of Amrasca biguttula biguttula was observed from $46^{\text {th }}$ to $7^{\text {th }}$ SMW $\left(13^{\text {th }}\right.$ November, 2016 to $12^{\text {th }}$ February, 2017). The incidence of leafhopper revealed that the peak incidence was recorded on $3^{\text {rd }}$ SMW $\left(15^{\text {th }}\right.$ January, 2017) with a mean number of 1.87 leafhopper per leaf and the lowest was recorded on $46^{\text {th }}$ SMW $\left(13^{\text {th }}\right.$ November, 2016), $6^{\text {th }}$ SMW (5 ${ }^{\text {th }}$ February, 2017) and $7^{\text {th }}$ SMW (12 ${ }^{\text {th }}$ February, 2017) each with a mean of 0.20 per leaf (Table 1 ).

A more or less similar finding with those recorded by Bhatnagar (2007) who reported that leafhopper population declined on $2^{\text {nd }}$ week of November and Thakur (2017) who reported peak activity of leafhopper during 3rd week of January. Correlation coefficient of various weather parameters and Amrasca biguttula biguttula population were found non-significant with minimum temperature, minimum relative humidity, maximum relative humidity and rainfall, while maximum temperature ( $\mathrm{r}=-0.862)$ exhibited a significant negative correlation (Table 2). 
Table.1 Seasonal incidence of major insect pests of potato and their natural enemies during Rabi season of 2016-2017

\begin{tabular}{|c|c|c|c|c|c|c|c|}
\hline \multirow{2}{*}{$\begin{array}{c}\text { Standard } \\
\text { Mean } \\
\text { Week } \\
\text { (SMW) }\end{array}$} & \multirow[t]{2}{*}{$\begin{array}{c}\text { Date of } \\
\text { observation }\end{array}$} & \multicolumn{4}{|c|}{$\begin{array}{l}\text { Insect pests population } \\
\text { (Mean number per leaf) }\end{array}$} & \multicolumn{2}{|c|}{$\begin{array}{l}\text { Natural enemy population } \\
\text { (Mean number per plant) }\end{array}$} \\
\hline & & $\begin{array}{l}\text { Potato } \\
\text { Aphid }\end{array}$ & Whitefly & Leafhopper & Mealybug & $\begin{array}{l}\text { Lady bird } \\
\text { beetle }\end{array}$ & Spider \\
\hline 46 & 13.11 .16 & 0.00 & 0.00 & 0.20 & 0.00 & 0.00 & 0.00 \\
\hline 47 & 20.11 .16 & 1.45 & 0.20 & 0.33 & 0.20 & 0.07 & 0.13 \\
\hline 48 & 27.11 .16 & 1.73 & 0.33 & 0.50 & 0.33 & 0.13 & 0.07 \\
\hline 49 & 04.12 .16 & 1.80 & 0.50 & 0.67 & 0.67 & 0.27 & 0.67 \\
\hline 50 & 11.12 .16 & 2.80 & 0.67 & 0.87 & 0.87 & 0.20 & 0.27 \\
\hline 51 & 18.12 .16 & 3.83 & 0.83 & 1.00 & 1.33 & 0.33 & 0.20 \\
\hline 52 & 25.12 .16 & 4.13 & 1.00 & 1.20 & 2.67 & 0.33 & 0.13 \\
\hline 01 & 01.01 .17 & 15.07 & 1.67 & 1.33 & 3.20 & 0.20 & 0.07 \\
\hline 02 & 08.01 .17 & 17.53 & 0.93 & 1.67 & 3.07 & 0.20 & 0.07 \\
\hline 03 & 15.01 .17 & 21.13 & 0.77 & 1.87 & 2.47 & 0.20 & 0.13 \\
\hline 04 & 22.01 .17 & 23.93 & 0.67 & 0.67 & 1.67 & 0.27 & 0.20 \\
\hline 05 & 29.01 .17 & 16.93 & 0.50 & 0.33 & 0.67 & 0.40 & 0.47 \\
\hline 06 & 05.02 .17 & 8.13 & 0.33 & 0.20 & 0.33 & 0.20 & 0.47 \\
\hline 07 & 12.02 .17 & 5.20 & 0.20 & 0.20 & 0.20 & 0.00 & 0.07 \\
\hline
\end{tabular}


Table.2 Correlation coefficient (r) of major insect pests and natural enemies with abiotic factors in potato during Rabi season of 2016-2017

\begin{tabular}{|c|c|c|c|c|c|c|}
\hline \multirow{2}{*}{\multicolumn{2}{|c|}{ Arthropods }} & \multicolumn{2}{|c|}{$\begin{array}{c}\text { Temperature } \\
\left({ }^{\circ} \mathrm{C}\right)\end{array}$} & \multicolumn{2}{|c|}{ Relative humidity (\%) } & \multirow{3}{*}{$\begin{array}{c}\begin{array}{c}\text { Rainfall } \\
(\mathbf{m m})\end{array} \\
-0.163^{\mathrm{NS}}\end{array}$} \\
\hline & & Maximum & Minimum & Maximum & Minimum & \\
\hline \multirow{4}{*}{ 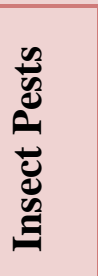 } & Potato Aphid & $-0.658 *$ & $-0.744 * *$ & $-0.345^{\mathrm{NS}}$ & $-0.398^{\mathrm{NS}}$ & \\
\hline & Whitefly & $-0.692 * *$ & $-0.457^{\mathrm{NS}}$ & $0.105^{\mathrm{NS}}$ & $-0.037^{\mathrm{NS}}$ & $0.330^{\mathrm{NS}}$ \\
\hline & Leafhopper & $-0.862 * *$ & $-0.467^{\mathrm{NS}}$ & $0.157^{\mathrm{NS}}$ & $0.018^{\mathrm{NS}}$ & $0.232^{\mathrm{NS}}$ \\
\hline & Mealybug & $-0.821 * *$ & $-0.506^{\mathrm{NS}}$ & $-0.024^{\mathrm{NS}}$ & $-0.069^{\mathrm{NS}}$ & $0.390^{\mathrm{NS}}$ \\
\hline \multirow{2}{*}{ 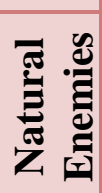 } & $\begin{array}{l}\text { Lady bird } \\
\text { beetle }\end{array}$ & $-0.561 *$ & $-0.348^{N S}$ & $-0.014^{\mathrm{NS}}$ & $0.109^{\mathrm{NS}}$ & $0.304^{\mathrm{NS}}$ \\
\hline & Spider & $0.156^{\mathrm{NS}}$ & $-0.143^{\mathrm{NS}}$ & $-0.143^{\mathrm{NS}}$ & $-0.071^{\mathrm{NS}}$ & $-0.162^{\mathrm{NS}}$ \\
\hline
\end{tabular}

* Significant at 5\% level of significance; ** Significant at $1 \%$ level of significance $\mathrm{NS}=$ Non-significant at $5 \%$ level of significance

A more or less similar finding was recorded by Felicity (2013) who observed a negative non-significant correlation with minimum temperature.

\section{Mealybug (Phenacoccus solenopsis)}

Phenacoccus solenopsis was first recorded during $47^{\text {th }}$ SMW on potato. The activity period of Phenacoccus solenopsis was observed from $47^{\text {th }}$ to $7^{\text {th }}$ SMW $\left(20^{\text {th }}\right.$ November, 2016 to $12^{\text {th }}$ February, 2017). The highest incidence was recorded on $1^{\text {st }}$ SMW $\left(8^{\text {th }}\right.$ January, 2017) with a mean of 3.20 per leaf, while the lowest on $47^{\text {th }}$ SMW $\left(20^{\text {th }}\right.$ November, 2016) and $7^{\text {th }}$ SMW $\left(12^{\text {th }}\right.$ February, 2017) each with a mean of 0.20 per leaf (Table 1).

Correlation studies between mealybug population and abiotic factors showed a negative significant correlation with maximum temperature $(r=-0.821)$ and negative nonsignificant correlation with minimum temperature, maximum and minimum relative humidity but showed a positive nonsignificant correlation with rainfall (Table 2).
Seasonal incidence of natural enemies

Lady bird beetle (Menochillus
sexmaculatus)

Menochillus sexmaculatus was first recorded during $47^{\text {th }}$ SMW on potato. The activity period of Menochillus sexmaculatus was observed from $47^{\text {th }}$ to $6^{\text {th }}$ SMW $\left(20^{\text {th }}\right.$ November, 2016 to $5^{\text {th }}$ February, 2017).

Maximum peak was recorded on $5^{\text {th }}$ MSW ( $29^{\text {th }}$ January, 2017) with a mean of 0.40 per plant and the lowest incidence was recorded on $47^{\text {th }}$ MSW $\left(20^{\text {th }}\right.$ November, 2016) with a mean of 0.07 per plant (Table 1).

Correlation studies between Menochillus sexmaculatus population and abiotic factors showed a negative non-significant correlation with minimum temperature $(r=-0.348)$ and maximum relative humidity $(\mathrm{r}=-0.014)$ and negative significant correlation with maximum temperature $(\mathrm{r}=-0.561)$ but showed a positive non-significant correlation with minimum relative humidity $(\mathrm{r}=0.109)$ and rainfall $(\mathrm{r}=0.304)$ (Table 2). 


\section{Spider (Oxyopes sp.)}

Oxyopes spp. was first recorded during $47^{\text {th }}$ SMW on potato. The activity period of Oxyopes sp. was observed from $47^{\text {th }}$ to $7^{\text {th }}$ SMW $\left(20^{\text {th }}\right.$ November, 2016 to $12^{\text {th }}$ February, 2017). The highest incidence of Oxyopes sp. was recorded on $49^{\text {th }}$ SMW $\left(4^{\text {th }}\right.$ December, 2016 ) with a mean of 0.67 per plant, while the lowest on $48^{\text {th }}$ SMW $\left(27^{\text {th }}\right.$ November, 2016), $1^{\text {st }}$ SMW ( $1^{\text {st }}$ January, 2017) and $2^{\text {nd }}$ SMW $\left(8^{\text {th }}\right.$ January, 2017) with a mean of 0.07 per plant (Table 1). Correlation studies between spider population and abiotic factors showed a negative non-significant correlation with minimum temperature $(\mathrm{r}=-0.143)$, maximum relative humidity $(\mathrm{r}=-0.143)$, minimum relative humidity $(\mathrm{r}=-0.071)$ and rainfall $(\mathrm{r}=-$ 0.162 ), but showed a positive non-significant correlation with maximum temperature $(\mathrm{r}=0.156)$ (Table 2).

\section{Acknowledgement}

Authors thank to Dr. Pankaj Neog, Assistant Professor, Department of Entomology, School of Agricultural Sciences and Rural Development, Nagaland University, Medziphema, Nagaland for his valuable suggestion and guidance throughout the entire course of investigation.

\section{References}

Anonymous. 2015. Horticultural Statistics at a Glance. pp 153-430.

Basavaraju, B. S., Chakravarthy, A. K., Doddabasappa, B. and Krishnamurthy, N. 2009. Yield loss estimation due to major insect and mite pests on potato in Karnataka. Karnataka Journal of Agricultural Sciences, 22: 597-600.

Bhatnagar, A. 2007. Incidence and succession of thrips, leaf hoppers and whitefly in combination of planting dates and potato varieties in Chambal region.
Annals of Plant Protection Sciences, 15 (1): 101-105.

Blackman, R. L. and Eastop, V. F. 2000. Aphids on the World's Crops: An Identification and Information Guide, 2nd Ed. John Wiley \& Sons Ltd., Chichester. pp 414.

Brunissen, L., Cherqui, A., Pelletier, Y., Vincent, C. and Giordanengo, P. 2009. Host-plant mediated interactions between two aphid species. Entomologia Experimentalis et Applicata, 132: 30-38.

Dhaliwal, G. S., Jindal, V. and Dhawan, A. K. 2010. Insect Pest Problems and Crop Losses: Changing Trends. Indian Journal of Ecology, 37 (1): 1-7.

Ebwongu, M. E., Adipala, M., Kyamanywa, S., Sekabembe, C. K. and Bhagsari, A. S. 2001. Influence of spatial arrangements in maize/potato intercrops on incidence of potato aphids and leaf hoppers in Uganda. African Crop Science Journal, 9 (1): 175-184.

Felicity. 2013. Pests management of potato (Solanum tuberosum L.) with certain plant extracts. M. Sc (Ag) Thesis, School of Agricultural Sciences and Rural Development, Nagaland University, Medziphema, Dimapur, Nagaland.

Konar, A. and Singh, J. 2009. Occurrence of aphids on various potato germplasms in eastern gangetic plains of West Bengal. The Journal of Plant Protection Sciences, 1 (1): 21-24.

Lanunochetla, Alemla, M. and Neog, P. 2012. Incidence of Aphid and Whitefly on Different Planting Dates in Relation to abiotic Factors in Potato Variety Kufri jyoti. International Journal of Bioresource and Stress Management, 3 (2): 239-241.

Shakur, M., Ullah, F., Naem, M., Amin, M., Saljoqi, A. U. R. and Zamin, M. 2007. 
Effect of various insecticides for the control of potato cutworm (Agrotis ipsilon, Noctuidae: Lepidoptera) at Kalam Swat. Sarhad Journal of Agriculture, 23 (2): 423-426. insect pests and their management through particle film technology on rabi potato at Raipur. M.Sc. (Ag) Thesis, Indira Gandhi Krishi Vishwavidhyalaya, Raipur.

Thakur, D. 2017.Seasonal incidence of major

\section{How to cite this article:}

Imlilemla Amlari, Pankaj Neog and Noyingthung Kikon. 2021. Seasonal Incidence of Major Insect Pests of Potato (Solanum tuberosum L.) and their Correlation with Abiotic Factors under Foothill Conditions of Nagaland. Int.J.Curr.Microbiol.App.Sci. 10(07): 222-228.

doi: https://doi.org/10.20546/ijcmas.2021.1007.024 